\title{
Frost Comes out of the Kremlin: \\ Changes in Property Law and the Adoption of the Civil Code in 1950
}

\author{
Jan Kuklík
}

Právnická fakulta, Univerzita Karlova

E-mail:kuklik@prf.cuni.cz

\section{Petra Skřejpková}

\author{
Právnická fakulta, Univerzita Karlova \\ E-mail: skrejpko@prf.cuni.cz
}

\begin{abstract}
:
The article deals with the transformation of the ownership structure in Czechoslovakia during the post-war period and particularly after the adoption of the Ninth-of-May Constitution in 1948. It also details the process of drafting and adopting the new Civil Code in 1950. The article tracks changes in the traditional understanding of the right of ownership that were incorporated into the legal system based on the Soviet legal model introduced by the codification.
\end{abstract}

Keywords:

Civil Code; property law; ownership; nationalization

DOI: $10.14712 / 2464689 X .2019 .28$

The text of the article is based on the book KUKLÍK, J. Czech Law in Historical Contexts. Prague: Karolinum, 2015.

\section{1) On the Way to Socialism}

In order to comprehend the further development of Czechoslovakia after World War II, it is necessary to understand that the Czechoslovak-Soviet relations already began to form at the beginning of World War II and resulted in the signing of a mutual agreement on 18 July 1941, as well as in the signing of the "Treaty of Friendship, Mutual Assistance and Post-war Cooperation" (12 December 1943). At that time, the Czechoslovak political representation, including President Dr. Edvard Beneš, was under the illusion that a gradual transformation of the Soviet system and its approximation to Western democracies were possible. The Soviet economy, its planning and "scientific management" were also 
subjects of these illusions. This treaty dictated the post-war foreign policy of our country, as well as its inner political development. The nationalization decrees of the President of the Republic later changed not only the ownership structure of the economy but also the overall structure of national income. Nationalization had thereby become an integral part of the then ongoing socialist economic and social reforms. This gradually paved the way for the communist power seizure. ${ }^{1}$

The communist or "socialist" political and legal systems were established in Czechoslovakia in 1948. The struggle for power between the democratic and communist forces culminated in February 1948, when the Communist Party seized political power with the help of collaborators from within other parties and by using the pressure of the workers' militia and mass demonstrations. Although the Communists also made use of threats and illegal means, the seizure of power was formally achieved within the Czechoslovak constitutional framework. The situation in Czechoslovakia in 1948 therefore differs if compared with other countries of the emerging Soviet Bloc. We can say that the Communist Party seized power by misusing the democratic structures of Czechoslovakia. The employment of other means, such as intimidation of political opponents, clearly shows the true totalitarian foundations of the new regime. It is now well documented that the coup was a longterm, planned subversion of the democratic system. Czechoslovak Communists always used the argument of "constitutional seizure of power" for their own ideological purposes. This semblance of legality of the seizure of power also influenced the first round of changes made to the Czechoslovak law in 1948 by using previously democratically established laws including those from interwar period or even 19th century Austria but in different political and ideological contexts, changing their interpretation or limiting their scope.

After the putsch, Czechoslovakia was a communist dictatorship with a semi-democratic façade, which was decorated mainly by the existence of several political parties within the continuation of the National Front, as well as by proclamations incorporated in the new Constitution adopted in May 1948. However, the Czechoslovak road to socialism, which was advocated at the beginning, was soon replaced with Soviet style Stalinism. The regime soon became an open dictatorship characterized by political trials (even against the leading members of the Communist Party), harsh punishment of political opponents and the Church, ${ }^{2}$ the confiscation of property, further nationalization, and the introduction of Soviet style collective farms in rural areas (forced collectivization). The regime was officially referred to by Communists themselves as the "dictatorship of the proletariat". The so-called Ninth-of-May Constitution of 1948 or May Constitution (the Constitutional Act of 9 May 1948, officially promulgated on 9 June 1948) ${ }^{3}$ replaced the 1920 Constitution and introduced the political system of the so-called People's Democracy. Work on the new document started in the summer of 1946. The new constitution preserved several similarities to the former "bourgeois" constitution but also contained a number of elements

1 KUKLÍK, J. et al. Vývoj československého práva 1945-1989. Praha: Linde, 2009. KUKLÍK, J. Czech law in historical contexts. Prague: Karolinum, 2015, p. 159 ff. For further literature see footnote 1 in our article on Family Law in this number.

2 Ibidem.

3 Ústava 9. května. 3rd ed. Praha: Ministerstvo informací, 1948, for text in English see: Constitution of the Czechoslovak Republic, Constitutional Act of May 9th, 1948. Prague: Czechoslovak Ministry of Education, 1948. 
borrowed from the "Stalin Constitution" of the Soviet Union. The function of the president as Head of the State was maintained contrary to other soviet satellites (except Germany) where the collective executive body was introduced. However, the final document was in such discrepancy with the former democratic order and so close to the Soviet model that President Dr. Edvard Beneš refused to sign it and resigned. ${ }^{4}$ We would like to stress that in the case of this constitution, one must not look at the mere text of the Constitution but also has to analyse the law in action. The Czechoslovak Constitution is a very good example of the principal difference between the law as it is in books and the law in action, ${ }^{5}$ as the Constitution was used as a fig leaf or a camouflage for the true nature of the communist regime in its initial stage. The May Constitution set several goals for the forthcoming changes in the Czechoslovak laws including the main fields of our interest - civil and family law.

Chapter Eight of the May Constitution was the most important, as it regulated the economic foundations of the communist regime. The main categories of means of production were either national (state) property, or the property of the people's cooperatives. Private property was restricted only to small enterprises with fewer than 50 employees and only to certain branches of industry. Directly after the February Coup of 1948, the Communists carried out a second wave of nationalization of the industry together with a extensive land reform and confiscation of the property of political opponents. State property was administered by the state either directly or through national enterprises. Private property was gradually limited only to small owners of land (up to 50 hectares) or small private business; all leading branches of industry were almost entirely nationalized between 1948 and 1950. Nationalization in Czechoslovakia was more rapid and extensive than in the German Democratic Republic, Poland, or Hungary. The land reform was a first step towards the collectivization of agriculture.

The Constitution deals with the possibility of communal property in connection with enterprises owned by national committees; however, this form of ownership ceased to exist in 1949, when the property of national committees was transferred to the state. In order to make a distinction between private ownership of a capitalist nature and the private belongings of individuals based on their work, a new type of ownership was implemented by the Constitution - the "individual ownership".

These modifications in the form of ownership were linked to the introduction of "scientific" Soviet style economic planning. The economy was centralized and directed in the form of Five-Year Economy Plans. The Constitution thus set important guidelines for changes in the concept of ownership and formed a platform for the extinction of the whole branch of commercial law.

The most important changes in the Czechoslovak law during the initial period after February 1948 were based on the Marxist-Leninist theory. It was for ideological reasons to designate the first period after communist accession to power as the dictatorship of the proletariat. Lenin's works as readdressed and simplified by Stalin (and also Vyshinski for Legal Theory and Criminal $\mathrm{Law}^{6}$ ), worked as an official ideology in the form of the socialist

4 TABORSKY, E. Communism in Czechoslovakia, 1948-1960. Princeton, N. J.: Princeton University Press, 1961.

5 Representing new dimension to the original idea of Roscoe Pound. See famous article by POUND, R. Law in Books and Law in Action. American Law Review, 1910, 44, p. 12 and following.

6 Andrey Y. Vyshinsky (1883-1954) was a Soviet politician, jurist and diplomat. He made friends with Stalin during their imprisonment after the revolution in 1905. Vyshinsky is generally known as state prosecutor 
theory of the state and law in Czechoslovakia as well. For civil law such a role was played mainly by a book by Anatolij Vasiljevich Venediktov on the State socialist ownership, which was translated into Czech in 1950 and was frequently referred to by Czechoslovak experts during codification process. ${ }^{7}$ The basis of his theory of property rights is that the subject of property rights of state socialist property is the socialist society itself as a whole - the people represented by their socialist state. Further he defines ownership as a right of an individual or legal entity (comprising state) to use means of production, in its interest and on the bases and in compliance with of the class structure of the society. ${ }^{8}$

The Czechoslovak legal setting was quickly determined by Soviet doctrine, even though it at first took the form of a simplified and scientifically low-level set of guidelines. In this respect, the changes in academia, especially at Law Faculties played an important role. However, some aspects of the Central European legal culture and Austrian laws or Czechoslovak laws enacted in the interwar period remained in force. This phenomenon will be the object of further detailed research as it will surely help to identify the reasons and scope of this aspect.

\section{2) Legislative Changes and the Preparation of the New Civil Code}

The first wave of transformation of the Czechoslovak laws was tied to the so-called twoyear legal plan of codification. At first the concept was discussed by political bodies of the Communist Party and new minister of justice, Alexej Čepička, asked the experts of the Law Commission of the Communist Party to prepare guidelines for changes of the Czechoslovak laws to fit with new political, social and economic system of People's Democracy. In March 1948 first proposal was made by professor of Church law and legal history Josef Tureček including the proposal to prepare new codes within a short period of two years. ${ }^{9}$ The Ministry of Justice was entrusted to evaluate the start of codification works in this respect and the new Communist Government mentioned the intention to prepare a series of new "socialist" codes to change the existing legal system according to the new political and ideological needs in its programme. The leadership of the Communist party including its head, Klement Gottwald, already in June 1948 urged the speedy changes including the derogation of "old, bourgeois laws" some of them being criticized to be from the period of enlightened absolutism. ${ }^{10}$ There were also special meetings held with the representatives of the Supreme Court with communist legal experts on the re-codification of Czechoslovak laws in summer 1948. The results were discussed by the Czechoslovak Government on 14 July 1948 and the Government entrusted the Ministry of Justice to prepare guidelines

of Joseph Stalin's Moscow trials and in the Nuremberg trials. Furthermore, he held the post of the Soviet Foreign Minister from 1949 to 1953, after having served as Deputy Foreign Minister under V. Molotov since 1940. He was also appointed head of the Institute of State and Law in the Soviet Academy of Sciences, where he developed his legal theories. See more: KUKLÍK et al. Vývoj československého práva 1945-1989. To his person VAKSBERG, A. Stalin's Prosecutor: The Life of Andrei Vyshinsky. New York: Grove Weidenfeld, 1990.

7 FRANTAlOVÁ, A. Právnická dvouletka a činnost politické komise 1948-1950. In: BLÁHOVÁ, I. BLAŽEK, L. - KUKLÍK, J. - ŠOUŠA, J. Právnická dvouletka: rekodifikace právního řádu, justice a správy v 50. letech 20. století. Praha: Auditorium, 2014, p. $91 \mathrm{ff}$.

8 VENEDIKTOV, A. V. Státní socialistické vlastnictví. Vol. 1. Praha: Orbis, 1950. Socialistické právo, p. $30 \mathrm{ff}$.

9 The National Archives, Prague, fund, 100/1. Generální sekretariát ÚV KSČ, 70/545.

10 BLÁHOVÁ - BLAŽEK - KUKLÍK - ŠOUŠA, op. cit., p. 12. 
defining the most important changes anticipated by the May Constitution of 1948 and to recodify the main branches of the Czechoslovak law. The deadline was set for September 1950 , i.e. in two years. That is why the re-codification process is known as a two-year legal plan to terminologically approximate it with the two-year economic plan of reconstruction and renewal of economy. During research in the archives, several new pieces of evidence have been discovered, especially the translations of Russian (Soviet) literature prepared by a special department of the Czechoslovak Ministry of Justice, as well as discussions and guidelines of the so called "political commission", which was entrusted with the codification works. ${ }^{11}$ The main outline of codification was already set by the Communist leadership in 1948, as well as during a special congress of "progressive" lawyers in 1949, where the new ideology, together with its compliance to the Soviet model, was discussed, ${ }^{12}$ and also during the IX. Party Congress of the Czechoslovak Communist Party. The Communists criticized the formalistic, apolitical and impartial "old" legal system; they also attacked the continuity of the "Austrian" legal system and Roman law foundations and terminology. ${ }^{13}$ They pointed out that the new law should assist the ideology, the working class and the establishment of a socialist society. The "new law" was seen as a mere tool for political and ideological aims, and as Klement Gottwald ${ }^{14}$ put it, "the law serves us to transform the society". As proclaimed several times by leading Communist politicians, the law had to express the will of the working class.

This resulted in the abolition of the traditional division of law into public and private and in their replacement by a universal legal system. This was another example of the intention to introduce the Soviet legal principles as soon as possible. Another objective was to simplify the legal system. The assumption was that simplified law would be more understandable for ordinary people. This approach was accompanied by changes in the interpretation of existing "old laws" with the aim to "fill them with new, socialist spirit" before they were abolished and replaced by new laws. ${ }^{15}$

The outcome of the two-year legal plan was a very rapid and efficient change, especially in civil and criminal law. Another goal of the codification was to unify the law applicable to the Czech lands and Slovakia, which was something that the whole interwar period tried to achieve but did not succeed. Various outcomes of codification drafts from the interwar period were used to speed up the preparation. Communists took advantage of these drafts and presented them as another example of the effectiveness of People's Democracy, in comparison with the unsuccessful twenty years of bourgeois interwar democracy. The Russian Civil Code from 1922 and the constitutional principles incorporated into the Soviet

11 BLÁHOVÁ - BLAŽEK - KUKLÍK - ŠOUŠA, op. cit. KUKLÍK, Czech law in historical contexts.

12 See especially the address by ČEPIČKA, A. Justiční listy, 1949, Vol. III, No. 8, 9.

13 For broader legal philosophical context of communist attacks against Roman law principles see BĚLOVSKÝ, P. The Law of Property in the Socialist Civil Codes of Czechoslovakia. Available at: https://www .academia.edu/40240306/The_Law_of_Property_in_Socialist_Civil_Codes_of_Czechoslovakia, p. 2. [online]. [cit. 15. 10. 2019].

14 Klement Gottwald (1896-1953) was a leader of the Communist Party of Czechoslovakia from 1929 until his death. He served as Prime Minister from July 1946 until June 1948, the first Communist to hold the post. In June 1948, he was elected Czechoslovakia's first Communist president.

15 From comparative perspective see GSOVSKI, V. - GRZYBOWSKI, K. (eds.). Government, Law and Courts in the Soviet Union and Eastern Europe, vol. 1, part I. Continuity of law. New York: Frederick Praeger, Inc., 1959, pp. 495-496. 
Constitution from 1936 served as a model for the authors of the codification. At the same time, they used the draft of the Civil Code, which was made during the inter-war period. Undoubtedly, the fact that some authors participated in the drafting and wording of both codifications was important. ${ }^{16}$

Two main commissions were set up in the beginning of the codification process. One was in charge of civil law, with sections dealing with substantive law and procedure. The same working procedure was used when working on criminal law. The two commission were directed by the so-called "political commission", which was the highest political and expert authority of the codification works reporting to the Ministry of Justice in 19481950. Its main objectives were to direct the discussions on the drafts of new laws and codes presented by particular expert committees and to influence and "control" its content ideologically. By examining its records, it was therefore possible for us to describe the political aspects of preparations of new laws.

Among those who significantly influenced functioning, establishment, competences and tasks of the political committee it is necessary to mention especially its chairman Dr. Adolf Dressler, deputy minister of justice ${ }^{17}$ Karel Klos, professor and dean of the Law Faculty Josef Tureček, Dr. Bedřich Rattinger, Dr. Jaromír Blažke or Karel Petrželka (head of the codification section of the Ministry of Justice). ${ }^{18}$ The political committee discussed certain important questions (for example the definition of ownership or the scope of the private ownership) directly with the Central Committee of the Communist Party and before such a political decision was accepted the codification process was put on halt.

The two years plan accomplishment was possible also because the ministry of justice secured collaboration of leading experts, including professor of Civil law Jan Krčmáŕ, who participated in the drafting of the proposal of Czechoslovak Civil Code in 1937. ${ }^{19}$ There were also other professors, judges or legal practitioners ready to join the expert committees.

The new Czechoslovak Civil Code (Act No. 141/1950 Coll.) was adopted in 1950. ${ }^{20}$ To a certain extent it rejected the Roman law tradition in private law. In general, one can conclude that civil law was misused for the purposes of the communist ideology. ${ }^{21}$ First important change to original Central European concepts of civil law was adoption of special Act on Family law in accordance with Polish law. ${ }^{22}$ The concept of family law as a new branch of law was the first example of the fragmenting of civil law. ${ }^{23}$ During the

16 BĚLOVSKÝ, P. Občanské právo. In: BOBEK, M. - MOLEK, P. - ŠIMÍČEK, V. (eds.). Komunistické právo v Československu. Brno: Masarykova univerzita, Mezinárodní politologický ústav, 2009, pp. 425-462.

17 See especially The National Archives, fund Ministerstvo spravedlnosti (Ministry of Justice), not analysed, meetings of political committee 1948-1950.

18 FRANTALOVA, A. Právnická dvouletka a činnost politické komise v letech 1948-1950. Disertační práce PF UK, Praha, 2019.

19 See for example KUKLÍK, J. Profesor Jan Krčmár̆. Pozapomenutá osobnost české civilistiky. Praha: Univerzita Karlova, 2008.

20 HIKL, M. The Civil Codes in Communist Czechoslovakia. Toronto: The Czechoslovak Foreign Institute in Exile, 1959, pp. 6-22, and FALADA, D. Codification of private law in the Czech Republic. Fundamina: A Journal of Legal History (South Africa), 2009, Vol. 15, No. 1, pp. 58-61.

21 GSOVSKI, V. - GRZYBOWSKI, K. (eds.). Government, Law and Courts in the Soviet Union and Eastern Europe, vol. II, part V, Sovietization of Civil Law, Czechoslovakia. New York: Frederick Praeger, Inc., 1959, pp. 1238-1276.

22 See article on Czech family law in this volume.

23 HIKL, op. cit., pp. 23-27. 
preparation of the Civil Code Soviet experiences (as well as common consultations with Polish experts $)^{24}$ were used and discussed. There were also special meetings with workers to test the "simplification" and people's character of new laws. For example, terms derived from Latin were frequently replaced by new terminology. Workers were represented also in the political committee of the Ministry of Justice to judge the ideological character of new laws.

The Code was divided into six parts and 570 articles and was much shorter than its Austrian predecessor which had 1502 articles. The ideological purpose of the Code and the new concept of private law were expressly stated in the first two parts of new Civil Code: introductory provisions of Part I remarking on the building of socialism and People's Democracy, and general provisions common to civil law as a whole. They set the predominance of the interest of the people democratic society over the interests of individual as the main interpretation principle of the whole code. It is interesting that this clause was added to the prepared text of the code in the final stages of codification and was discussed within the political bodies of the Communist party.

Part II of the Code enacted general provisions on such matters like the concepts and definitions of natural persons and legal entities, definition of a thing as an object of law and the description of a legally relevant expression of will and representation. ${ }^{25}$

In our comparison project we concentrated mainly on changes in the ownership and related rights, on the obligations and on the law of succession (inheritance). Part III of the Civil Code dealt with ownership and related rights.

Changes in the concept of ownership in fact followed the principles already set by the May Constitution of 1948. They were also influenced by two waves of nationalization of industry which lead to the establishment of dominance of the state sector. The first wave, specified by the Governmental Programme ${ }^{26}$ that was approved in 1945, was based on the nationalization of mines, key industrial enterprises, the food industry, banks, and insurance companies. The economic development of the country was to be further strengthened by confiscating the property of Germans, Hungarians, state traitors and war criminals. This form of confiscation was intended to serve as a form of punishment, as well as retribution for wrongs caused by these people during the Nazi occupation. Nationalized plants were merged, and larger units, called "state-owned national enterprises", were established. Promptly after the February Coup of 1948, the Communists carried out a second wave of industry nationalization together with a far-reaching land reform and confiscation of the property of political opponents. State property was managed by the state either directly or through national enterprises. Private property was gradually limited only to small holders of land (up to 50 hectares) or small private business; all important branches of industry were almost completely nationalized between 1948 and 1950. The land reform was the

24 The National Archives, fund Ministerstvo spravedlnosti, not analysed, comparison between Polish and Czechoslovak preparatory materials on Civil Code still not excluding the possibility of one common Civil Code for Poland and Czechoslovakia, August 1949, and Zápis ze schůze politické komise ze dne 31. 1. 1949. See also PETRŽELKA, K. Perspektivy spolupráce československých a polských právníků. Právník, 1949, No. 1. p. 57 ff.

25 FALADA, op. cit., p. 59

26 KAPLAN, K. Pět kapitol o Únoru. Brno: Doplněk, 1997. 
first step towards the collectivization of agriculture. The ownership of cooperative farms was established. ${ }^{27}$

The Constitution granted the possibility of communal property in connection with enterprises owned by national committees; however, this form of ownership ceased to exist in 1949, when the property of national committees was transferred to state ownership. This strengthened the state sector even more than the second wave of nationalization. As it was necessary to make a distinction between private ownership of a capitalist nature and private belongings of individuals aquired by their work, a new type of ownership was implemented by the Constitution called "individual ownership". ${ }^{28}$ Based on the theory that was developed by Venediktov ${ }^{29}$ this form of ownership was derived from socialist state property and was the result of work (and remuneration for this work) for the development of this property.

National property and the property of people's cooperatives was proclaimed to be a socialist type of ownership and given priority. The most important entities were national enterprises, which were governed by special laws. They were put in charge of with national (state) property only for the purposes of operational administration and were subjected to the economic plan and directives of the planning authorities. One of the prominent Czech lawyers who took part in the codification process was Viktor Knapp, who later became a leading Czech legal theoretician; he explained the purpose of the adoption of the new Civil Code as follows: "to liquidate the remnants of bourgeois property relations, as well as bourgeois thinking in our society... to strengthen and protect socialist ownership and to observe the rules of the socialist community life ..." $" 30$

The new concept of socialist ownership was accompanied by changes in all other aspects of property law and mortgages. The entire part was based on favourable treatment of the socialist owners. Socialist legal entities - especially national enterprises - were treated preferably in other parts of Civil Code as well. The degree of protection of private owners was far lesser than that of "socialist" or "individual" owners. The owner did not only enjoy rights but was also subject to obligations and numerous limitations. The private interest was subjected to the public one. If there were some concepts of Austrian Civil Code of 1811 left (this was mainly the case for certain passages dealing with easements-servitudes), they were limited in their real operation in practise and in all cases simplified.

The code abolished the generally accepted principle of Roman Law superficies solo cedit $(\S 25, \S 155) .{ }^{31}$ The code declared land and buildings (with the exception of temporary buildings) for real estate. Permanent buildings were no longer part of the land, but

27 KOČVARA, Š. The Sovietization of Czechoslovak farming, Standard Charter of the Unified Agricultural Cooperative in Czechoslovakia of February 17, 1953. Mid European Law Project. Washington, D. C.: Library of Congress, 1954, pp. 7-11.

28 ČÍŽKOVSKÁ, V. Osobní vlastnictví a jeho úprava v evropských socialistických právních řádech. Acta Universitatis Carolinae. Iuridica, 1974, No. 3.

29 SPIŠIAK, J. A. V. Venediktov. Štátne socialistické vlastníctvo. Pravny obzor, 1950, XXXIII, p. 589.

30 KNAPP, V. Vlastnictví v lidové demokracii: právni úprava vlastnictví v Československé republice. Praha: Orbis 1952, p. 67. See also his memoires, where he is trying to play down his original zeal to bring about radical changes into the Civil Code: KNAPP, V. Proměny času: vzpomínky Nestora české právní vědy. Prague: Prospektrum, 1998, pp. 121-122.

31 NOVOHRADSKY, V. Opustenie Zasady Superficies Solo Cedit a Jeho Dosledky. Pravny Obzor, 1951, XXXIV, pp. 346-352. 
separate real estate. The old principle superficies solo cedit became limited to what one produced on land, that is, to plants. Temporary buildings (cottages, kiosks), as hitherto, were considered separate movable things. As a result, owners of land and owners of buildings might be different persons (subjects).

Part IV of the Civil Code 1950, dealing with obligations (arising both from contracts and from torts), introduced equally significant changes. The Austrian Commercial Code was abolished and the Civil Code took over its function. Obligations could be formed not only on the basis of an agreement between parties, but in the case of "needs of economic planning" also by direct decisions of the planning authorities. Obligations could be changed or terminated on the basis of the same reasoning. When the Draft of the Civil Code was presented to the National Assembly, the Government expressly stated that "the law of contracts shall serve primarily the uniform economic plan... and the economic plan was designed to direct all the economic activities and in particular trades, production and transport." National enterprises were of cardinal importance, since they were governed by special laws; for example, industrial national enterprises were regulated by the Act on National Enterprises of 1950. They were entrusted with national (state) property only for operational administration and were subjected to the economic plan and directives of the planning authorities. The Government, in the form of Governmental decrees (for example, Decree No. 33 of 28 May 1955) set specific rules for the so-called economic contracts of national enterprises dealing with the supply of goods, performance of work, or rendering of services. Although a new Act on Joint Stock Companies was enacted in 1949, in practice the majority of private companies was either put under national administration, was nationalized, or simply ceased to be operational (even though they were sometimes liquidated years later). On the other hand, the Act on Joint Stock Companies of 1949 strengthened the concession system in respect to the creation of these entities, stressing state supervision. Administrative offices were left with sheer arbitrariness in their licensing and interference. Limited Liability Companies had to submit an application for state permits and approvals statutes within 6 months from the effective date (publication) of the Act, otherwise they would have gone into liquidation.

In addition a new method of solving disputes was introduced. Disputes between national enterprises and other legal entities within the socialist sector were dealt with in most cases (in particular concerning production, services and work) through a new type of state supported and supervised arbitration, once more according to the Soviet model. ${ }^{32}$ There was a special Act No. 99/1950 Sb. on Economic Contracts and Government Arbitration, amended by governmental decrees in 1953 and 1954. There was a specialized arbitration agency for cooperatives. Cooperatives in the field of agriculture were regulated by a specific law from 1949 and their concept lead to imperative changes of the concept of ownership, namely that the usage of land became more important than the formal ownership.

The law of inheritance was regulated by Part V of the Code. The preparation for the new law of succession within the two-years legal plan was closely connected to the above-mentioned changes in ownership and related rights. A very interesting feature of the codifi-

32 HAZARD, L. N. - SHAPIRO, I. - MAGGS, P. B. The Soviet Legal system, Contemporary Documentation and Historical Commentary. New York: Published for the Parker School of Foreign and Comparative Law, Columbia University, New York, by Oceana Publications, 1969, pp. 272-273. 
cation of this part of civil law was clash between radical (ideologically based) concepts advocating the abolition of inheritance and the more pragmatic approach. The Civil Code distinguished succession based on a last will and on intestate succession. A combination of both titles was possible. Intestate succession was preferable. Socialist legal theory supported the idea that there was no real interest within the socialist society to allow the testator to dispose of his/her belongings after death freely. Succession law therefore failed, to a certain extent, to respect the last will, and the law of inheritance as a whole was simplified. It again favoured socialist and personal ownership over private ownership. The most severe limits concerning testation were imposed on the private owners of land.

The Part VI. of the Code dealt with final and transitional provisions. This part abolished number of laws including the Austrian Civil Code of 1811 (with the exception of labour contract) and the Austrian Commercial Code.

\section{Conclusions}

The unification of civil law on the whole territory of Czechoslovakia was one of the often highly evaluated positive features of the Civil Code. The Code naturally conformed to the time it was created and reflected its socio-political changes. The Civil Code of 1950, which was prepared during the two-years plan of recodification of Czechoslovak laws brought important changes into the civil law and served as an important tool to introduce a new socialist social and political order. It complied with the new revolutionary political program created by the Communist Party. As such it concentrated mainly on changes in the concept of ownership and contracts to serve new economic order of centrally planned economy and to introduce principles of new Constitution of May 1948 as well as principles derived from the Soviet law. Despite innovative tendencies that reflected these requirements, which were applied when drafting the new Civil Code, it nevertheless still maintained (even though mostly because of the lack of time to bring more discontinuities) the most important legal principles that are typical for the European continental legal tradition. We can therefore state that there was a certain continuation of the former development even if deformed by the new ideology. The most important however was how the provisions of the Civil Code were applied in practise and interpreted by new system of people's courts and procurators. It soon became clear that it was a mere first step towards the more complex changes of Czechoslovak society and legal order.

The unification of civil law on the whole territory of Czechoslovakia was one of the often highly evaluated positive features of the Civil Code. 